\title{
MITRAL VALVOTOMY IN SITUS INVERSUS WITH ASSOCIATED SKELETAL ANOMALIES
}

\author{
BY \\ E. T. L. DAVIES, J. P. DUFFY, AND H. H. KAMDAR \\ From the London Chest Hospital, London E. 2
}

The first case of mitral stenosis in a patient with situs inversus was reported from this hospital in 1911 (Owen). We have found four reports of mitral valvotomy in such cases (Berkowitz and Likoff, 1954; Koshy et al., 1955; Naef, 1957; Michaud et al., 1959) and a fifth is reported here.

Viscott (1960) collected some 900 previously reported cases of complete situs inversus and suggested that its incidence was 0.007 per cent (approximately $1: 13,600$ ). The coincidence of this condition with rheumatic heart disease must, therefore, be rare. Other congenital abnormalities may be present in the cardiovascular and respiratory systems, in the alimentary and urinary tracts, and in the skeleton. Johnson (1949) states, "It appears that the varieties of transposition are legion, the associated congenital anomalies are numerous and the person with situs inversus is as susceptible to acquired diseases as is one without it".

\section{Case Report}

A woman aged 32 was admitted to hospital in December 1962 complaining of breathlessness on exertion and recurrent winter bronchitis. Shortness of breath was first noticed in 1951 during her sole pregnancy, which was otherwise uncomplicated. She produced very little sputum and had never had hæmoptysis.

Mitral stenosis had been diagnosed in 1954, when situs inversus and skeletal anomalies were also noted. There was no history of rheumatic fever or chorea. There was no known family incidence of situs inversus but it is of interest that the patient is a twin, the other, of unknown sex, having been stillborn. There are no other twins in the family.

In 1957 laparotomy was performed and situs inversus of the abdominal viscera with acute salpingitis was found.

On physical examination she was well developed with marked cervico-dorsal kyphoscoliosis which resulted in asymmetry of the neck and thorax. There was also slight facial asymmetry. A small, firm, nodular goitre was present with no clinical evidence of disturbed thyroid function.

The pulse was regular and small and the blood pressure was $145 / 80 \mathrm{~mm}$. Hg. The jugular venous pulse was raised $3 \mathrm{~cm}$. above the sternal angle with the patient at $30^{\circ}$ to the horizontal. There was no œdema. The apex beat was felt in the fifth right intercostal space $4 \frac{1}{2}$ inches $(11.3 \mathrm{~cm}$.) from the midline and was tapping in character. No thrills were palpated.

On auscultation the first sound and the pulmonary component of the second sound were accentuated. A presystolic murmur, an opening snap, and a low-pitched diastolic murmur of moderate length were heard at the apex. A short ejection systolic murmur was maximal over the second left interspace. The liver dullness was on the left side and the gastric resonance on the right.

The electrocardiogram was typical of dextrocardia with a mean frontal QRS vector of $160^{\circ}$, inversion of all complexes in lead I, apparent interchanging of leads II and III, and tall R waves in V4R and V5R with the transitional zone at V3R. A P mitrale was present. Præcordial leads taken over the right chest in positions analogous to the conventional ones showed a normal evolution of the QRS complex.

Chest radiography confirmed the presence of dextrocardia and a penetrated view showed enlargement of the left atrium. A skiagram of the spine (Fig. 1) revealed cervico-dorsal scoliosis convex to the left with 13 dorsal vertebræ, those at D2, D5, and D8 being left-sided hemivertebræ. Consequently there were 13 
ribs on the left and 10 on the right side. A spina bifida occulta of C7 and D1 was also noted. The lumbar spine and sacrum were normal. Skiagrams of the skull showed asymmetry, the left side being smaller, and bilateral plaques of calcification in the tentorium cerebelli. The paranasal sinuses appeared normal.

Mitral valvotomy was performed in January 1963. Approach was by a postero-lateral thoracotomy through the upper border of the sixth rib on the right side. The contents of the right hemithorax were consistent with complete situs inversus: the right lung was divided into two lobes and the heart and great vessels were typical of mirror-image dextrocardia. No other congenital abnormality of the cardiovascular system was evident. The "left" atrium was moderately enlarged, the atrial appendage being normal in size; neither contained clot. The surgeon's left index finger was introduced through an incision in the atrial appendage and the mitral valve was found to be $4.5 \mathrm{~cm}$. in circumference (approximately $1.4 \mathrm{~cm}$. diameter). The cusps were mobile and there was no calcification or regurgitation. The commissures could not be split with the finger; a transventricular dilator was, therefore, introduced through an incision at the apex of the "left" ventricle and opened to $3.6 \mathrm{~cm}$., splitting the antero-lateral commissure fully and the postero-medial commissure almost fully. No regurgitant stream was detected.

The post-operative course was uneventful; on assessment later a soft pansystolic murmur, a soft third heart sound, and a short diastolic murmur were heard at the apex. Histology of the atrial appendage showed Aschoff bodies in the subendocardial tissues, confirming the rheumatic ætiology of the mitral stenosis.

\section{Discussion}

Mitral valvotomy in situs inversus presents special problems of orientation for the surgeon. In addition to the unusual spatial relations the mitral valve is explored with the "uneducated" left index finger and the transventricular dilator operated with the right hand. In other respects the operation does not differ from that performed on patients with normal situs.

Malformations of the spine with situs inversus have been described by many authors: they include hemivertebræ (Torgersen, 1948, 1949; Berkovits and Mándi, 1962), spina bifida occulta (Johnson, 1949; Torgersen, 1949; Berkovits and Mándi, 1962), six lumbar vertebræ (Torgersen, 1948, 1949), hypoplasia of a lumbar vertebra (Torgersen, 1948), lumbo-sacral vertebra (Torgersen, 1948; Warner, 1956), absence of coccyx or sacrum (Price, 1933; Torgersen, 1948), and the Klippel-Feil syndrome (Kopyść and Borowicz, 1957). Cervical ribs (Johnson, 1949; Berkovits and Mándi, 1962) and other anomalies of the ribs (Chenebault and Le Pape, 1956) have also been noted.

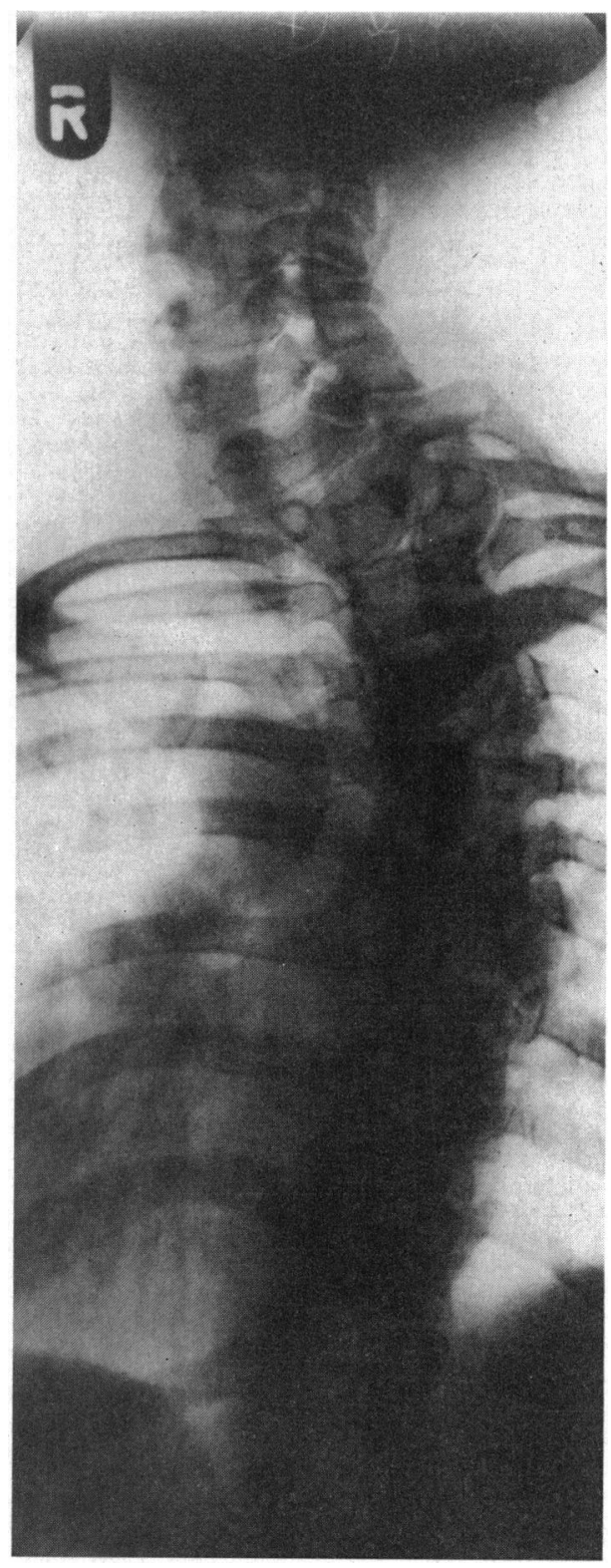

FIG. 1.-Skiagram of spine showing cervicodorsal scoliosis convex to the left with 13 dorsal vertebræ, those at D2, D5, and D8 being left-sided hemivertebræ. There are 13 ribs on the left and 10 on the right but the last pair are not well seen in this film. A spina bifida occulta of C7 and D1 is present. 
Twinning, situs inversus, and congenital anomalies are conditions not uncommonly associated with one another. All three were present in our patient.

The ætiology of situs inversus remains uncertain. One hypothesis suggests that it is related to the survival of one of twins (Viscott, 1960). If this is so it seems likely that an abnormal division of the developing zygote was responsible for the twinning, the abnormal asymmetry, and the congenital defects. It is of interest to note that 25 per cent of identical twins are said to show some degree of mirror imaging (Hamilton, Boyd, and Mossman, 1962).

This theory implies that where a patient with situs inversus is not known to be a twin the second twin has died in utero or in early life. Our early scepticism on this score was shaken when our patient learnt for the first time from an elder sister, as a result of our inquiries, that she had had a stillborn twin.

\section{Summary}

A patient with complete situs inversus who underwent valvotomy for rheumatic mitral stenosis is described. Skeletal anomalies were also present.

Previous reports of malformations of the spine and ribs occurring in patients with situs inversus are reviewed and one theory of the ætiology of situs inversus briefly considered.

We wish to thank Dr. G. B. L. Laird of Mile End Hospital, Dr. R. V. Gibson, and Mr. J. R. Belcher for permission to publish this account of a patient under their care.

\section{References}

Berkovits, L., and Mándi, A. (1962). Situs inversus cordis társulása halmozott csigolya fejlödési rendellenességgel. Magy. Radiol., 14, 158.

Berkowitz, D., and Likoff, W. (1954). Mitral stenosis complicating situs inversus. A case successfully treated by commissurotomy. Ann. intern. Med., 40, 784.

Chenebault, J., and Le Pape, J. (1956). Sur un cas de syndrome de Kartagener associé à des anomalies costales et à une tuberculose pulmonaire. Maroc méd., 35, 45.

Hamilton, W. J., Boyd, J. D., and Mossman, H. W. (1962). Human Embryology, 3rd ed. Heffer, Cambridge.

Johnson, J. R. (1949). Situs inversus with associated abnormalities. Arch. Surg., 58, 149.

Kopyść, Z., and Borowicz, S. (1957). Complete reverse position of viscera with congenital heart failure and KlippelFeil syndrome. Pediatria Polska, 32, 291.

Koshy, P., Thomas, T., Benjamin, V., and Gopinath, N. (1955). Mitral valvotomy for dextrocardia with mitral stenosis. A case report. Brit. med. J., 1, 1007.

Michaud, P., Perrin, A., Saubier, E., and Maret, G. (1959). Commissurotomie mitrale sur situs inversus. Lyon chir., 55, 606.

Naef, A. P. (1957). La commissurotomie par thoracotomie droite pour R.M. et situs inversus. Ann. Chir., 11, 1339.

Owen, S. A. (1911). A case of complete transposition of the viscera, associated with mitral stenosis; including a description of the electrocardiographic tracings. Heart, $3,113$.

Price, P. B. (1933). Plastic operations for incontinence of urine and of feces. Arch. Surg., 26, 1043.

Torgersen, J. (1948). Anomalies of the spine in anomalies of viscera and constitution. Acta radiol. (Stockh.), 29, 311.

- (1949). Genic factors in visceral asymmetry and in the development and pathologic changes of lungs, heart, and abdominal organs. Arch. Path., 47, 566.

Viscott, D. S. (1960). Situs inversus totalis. Bull. Tufts New Engl. med. Cent., 6, 199.

Warner, R. R. Pichel (1956). Situs inversus of gastro-intestinal tract. U.S. armed Forces med., J., 7, 1521. 